\title{
From Fordist to neo-liberal urban spaces in times of de-industrialization: a conceptual frame for a complex relationship
}

\author{
Arndt Neumann* \\ Wissenschaftlicher Mitarbeiter, Geschichte der Europäischen Moderne, FernUniversität in Hagen \\ Universitätsstraße 33B, 58084 Hagen, Germany \\ ${ }^{\star}$ Corresponding author. Email: arndt.neumann@fernuni-hagen.de
}

(First published online 14 May 2019)

\begin{abstract}
How did the complex relationship between working worlds and urban spaces change in Hamburg in times of de-industrialization? To answer this question, I focus on Hamburg's history from 1960 to 2008. Starting from the idea of a cumulative structural break, I develop a typology of Fordist and neo-liberal urban spaces and distinguish seven dimensions of change: from international division of labour to globalization, from industrial production to creativity, from rationalization to digitalization, from centralization to networks, from functional zoning to blurred boundaries, from social security to precarity and from suburbanization to the renaissance of the inner city. Finally, I consider whether this typology is valid for other European cities.
\end{abstract}

In 1997, Hamburg's social democratic mayor, Henning Voscherau, gave a widely publicized speech to local entrepreneurs, in which he presented the urban regeneration project HafenCity. ${ }^{1} \mathrm{He}$ argued that if Hamburg wanted to survive the 'international metropolitan competition', ${ }^{2}$ it had to reframe its economic policy. The service sector would generate economic growth in future, from logistics and finance to culture and tourism. In particular, 'multimedia's was supposed to reinvigorate the city. According to German newspapers, media companies would create approximately 150,000 jobs until the year $2000 .{ }^{4}$ To attract parts of this sector to Hamburg, the municipal government had to enlarge the city centre. For this reason, Voscherau planned to construct office buildings, cultural institutions and residential buildings inside the existing port area. He underlined the historic significance of

\footnotetext{
${ }^{1}$ H. Voscherau, 'Vortrag auf dem Übersee-Tag: 7.5.1997', in Der Übersee-Club Hamburg (ed.), Jahrbuch 1996/97 (Hamburg, 1998), 9-20.

${ }^{2}$ Ibid., 11.

${ }^{3}$ Ibid., 13 .

${ }^{4}$ Ibid.

(C) The Author(s), 2019. Published by Cambridge University Press. This is an Open Access article, distributed under the terms of the Creative Commons Attribution licence (http://creativecommons.org/licenses/by/4.0/), which permits unrestricted re-use, distribution, and reproduction in any medium, provided the original work is properly cited.
} 
his decision and compared the process of building the new district to the industrialization of the harbour in the nineteenth century. ${ }^{5}$

Against this background, the following question arises: how did the complex relationship between working worlds and urban spaces change in Hamburg in times of de-industrialization? To answer this question, I will first discuss the correlation between working worlds and urban spaces in general. Starting from a casestudy of Hamburg's history from 1960 to 2008, I then develop a conceptual frame for the different overlapping dimensions of change. Finally, I consider whether this conceptual frame is valid for other European cities.

\section{Working worlds and urban spaces}

Anselm Doering-Manteuffel and Lutz Raphael's analysis is the main starting point for this article. ${ }^{6}$ They make the case for adjusting the conception of contemporary history. Instead of getting lost in individual research, contemporary historians should develop an overarching framework, with a distinct socio-economic focus. They therefore concentrate on the 'cumulative structural break, ${ }^{7}$ which transformed European societies from the 1970s. While the 'Fordist production regime' fell apart, the rise of the 'digital financial market capitalism' began. ${ }^{8}$ The concept of a cumulative structural break is crucial for two reasons. First, it emphasizes the discontinuity rather than the stability of socio-economic structures and, second, it explains this transition not by one single development, such as the decline of certain industrial sectors, but through various intersecting shifts.

One of the key elements of this transition was the radical change of working worlds. While industrial labour lost its central role, other types of work became increasingly important. ${ }^{9}$ The clear boundary between paid and unpaid work began to disintegrate. ${ }^{10}$ To grasp the full scope of these trends, this article relies on a broad concept of work, which incorporates industrial workers as well as clerks, creative workers and housewives. At the same time, I focus on spatial effects. The radical change of working worlds strongly affected urban spaces. Every building is oriented towards certain activities. Among them, work is one of the most relevant. If the type of work changes, the buildings tend to change too. They are converted, they decay or they are replaced. Accordingly, facilities like industrial plants, offices, internet start-ups and private kitchens reconstruct the ways in which the conjunction between work and space has altered.

\footnotetext{
${ }^{5}$ J. Weinhold, 'Port culture: maritime entertainment and urban revitalisation, 1950-2000', in M. Heßler and C. Zimmermann (eds.), Creative Urban Milieus: Historical Perspectives on Culture, Economy, and the City (Frankfurt am Main, 2008), 179-205.

${ }^{6}$ A. Doering-Manteuffel and L. Raphael, Nach dem Boom: Perspektiven auf die Zeitgeschichte seit 1970, 2nd edn (Göttingen, 2010).

${ }^{7}$ Perspectives on the History of Western European Industrial Societies after 1970, www.nach-dem-boom. uni-tuebingen.de/projekt/projekt_en.php, accessed 30 Oct. 2017.

${ }^{8}$ Doering-Manteuffel and Raphael, Nach dem Boom, 27.

${ }^{9} \mathrm{~K}$. Andresen et al. (eds.), Nach dem Strukturbruch? Kontinuität und Wandel von Arbeitswelten (Bonn, 2011).

${ }^{10} \mathrm{~B}$. Duden, 'Kontinuität oder Epochenbruch? Zeitenwende oder geschichtliche Schwelle? Zur Zeitgeschichte der Integration der häuslichen Ökonomie von Frauen in die formelle Ökonomie', L'Homme. Europäische Zeitschrift für Feministische Geschichtswissenschaft, 25 (2014), 103-20.
} 
The cumulative structural break since the 1970s and the closely linked radical change in working worlds are essential to my argument. In contrast to recent studies in urban history, I assume that the evolving relationship between industry and the city characterized the second half of the twentieth century. ${ }^{11}$ As recently as the 1960 s and early 1970s, the interdependence reached its peak. Coal mines, steel mills and shipyards, which came into existence in the nineteenth century, still shaped many European cities. Furthermore, modernist architecture and town planning transferred the basic principles of industrial production onto the whole society. Since 1973, and this is crucial, the relationship disintegrated, from the decline of heavy industry to the rise of postmodern architecture. The global financial markets replaced industry as the most powerful influence on urban development. Based on the changing relationship between industry and city, I distinguish two different types of urban space. The first category, which was most notable in the 1960s and early 1970s, I term Fordist urban space. ${ }^{12}$ A second type, which emerged after 1989, I categorize as neo-liberal urban space. ${ }^{13}$

\section{Seven dimensions of change}

The ideas sketched out in the preceding paragraphs enable us to analyse how the conjunction between working worlds and urban spaces has developed in Hamburg since the 1970s. It stresses the discontinuity of socio-economic developments, the diverse forms of work, the built environment as a crucial source and the changing link between industry and city. These general assumptions have been the starting point of my research. ${ }^{14}$ To review them, I have focused on a case-study of Hamburg's history from 1960 to $2008 .{ }^{15}$ My main sources have been statistics, concept papers, architecture, documents of social movements and press releases. I have distinguished between three periods of time: the boom years from 1960 to 1973, the crisis from 1973 to 1989 and the growing city from 1989 to 2008. These periods correspond to four different working worlds, which were related to four different urban spaces: domestic work in suburban neighbourhoods and large housing estates, industrial and transport work in the harbour, office work in the city centre and a sequence of different forms of work in the urban neighbourhoods. In this article, my empirical findings are only mentioned briefly. I rather put emphasis on a typology, which captures the significant shifts.

Based on the case-study of Hamburg's history from 1960 to 2008, I have identified the most important differences between Fordist and neo-liberal urban spaces. Seven dimensions define this transformation: (1) from international division of

\footnotetext{
${ }^{11}$ F. Lenger, Metropolen der Moderne. Eine europäische Stadtgeschichte seit 1850 (Munich, 2013).

${ }^{12}$ A. von Saldern, 'Fordist elements of the industrial city in Germany and the United States', in C. Zimmermann (ed.), Industrial Cities: History and Future (Frankfurt am Main, 2013), 135-58; H. Häußermann et al., Stadtpolitik (Frankfurt am Main, 2008).

${ }^{13}$ M. Mayer, 'Urbane soziale Bewegungen in der neoliberalisierenden Stadt', Sub urban. Zeitschrift für kritische Stadtforschung, 1 (2013), 155-68; D. Harvey, The Neoliberal City: A Talk at Dickinson College, 1 Feb. 2007, www.youtube.com/watch?v=rfd5kHb-Hc8, accessed 30 Oct. 2017.

${ }^{14}$ A. Neumann, Unternehmen Hamburg: Eine Geschichte der neoliberalen Stadt (Göttingen, 2018).

${ }^{15}$ Forschungsstelle für Zeitgeschichte in Hamburg (ed.), 19 Tage Hamburg: Ereignisse und Entwicklungen der Stadtgeschichte seit den fünfziger Jahren (Munich, 2012).
} 
labour to globalization, (2) from industrial production to creativity, (3) from rationalization to digitalization, (4) from centralization to networks, (5) from functional zoning to blurred boundaries, (6) from social security to precarity, (7) from suburbanization to the renaissance of the inner city. In the following sections I explain these dimensions and illustrate each of them with an example from the case-study.

The first dimension: from international division of labour to globalization. During the boom years, colonialism strongly influenced the world economy. While the centres of industrial production were located in western Europe, North America and Japan, large parts of Asia, Africa and South America were limited to supplying raw materials. This international division of labour determined the trade flows. ${ }^{16}$ The port of Hamburg imported raw materials und exported industrial products. When oil replaced coal as the most important energy source, this international division of labour reached its last peak. The industrial structure of Hamburg was based on these trade flows. Most factories located in the port area refined raw material. Multinationals built new oil refineries and chemical plants in the post-war period. In addition, Hamburg was one of the global centres of shipbuilding, notably for supertankers. The rise of the petroleum industry not only determined the harbour and industrial areas. In the city centre, the oil companies built new office buildings for their expanding management. And cheap oil was one of the driving forces behind mass motorization and suburbanization.

The OPEC oil embargo from 1973 and the Iranian Revolution from 1979 proved disruptive for Hamburg. They pointed to a global shift of power. While the terms of trade improved significantly for the oil-exporting countries, the era of cheap oil ended in western Europe and North America triggering an economic crisis. New global centres of industrial production emerged in East Asia. The global pay gap, which the strength of the western labour movement had caused, enabled the new competitors to gain more and more market share. In contrast, many factories closed down in Hamburg in the 1970s and 1980s. Shipbuilding and heavy industry lost their central role. Due to changing trade flows, the container port and the logistic sector assumed a growing importance. Since the late 1980s, the import of industrial products has determined the port of Hamburg. Huge containerships transported industrial goods, which thousands of Chinese factories produced, to western Europe, particularly in the early 2000s, when globalization peaked. Alongside the dominance of global financial markets, the rise of East Asia characterized the last wave of globalization. ${ }^{17}$

The crisis of shipbuilding exemplifies how the process of globalization affected Hamburg's economy. In the boom years, the city was one of the world leaders for shipbuilding. In 1958, about 34,000 employees worked in the industry. ${ }^{18}$ The five major shipyards, which maintained close business relations with local shipping

\footnotetext{
${ }^{16}$ H.J. Puhle (ed.), Lateinamerika: Historische Realität und Dependencia-Theorien (Hamburg, 1977); A.G. Frank, Capitalism and Underdevelopment in Latin America: Historical Studies of Chile and Brazil (New York, 1967).

${ }^{17}$ L. Raphael, 'Die Geschichte der Bundesrepublik schreiben als Globalisierungsgeschichte', in F. Bajohr et al. (eds.), Mehr als eine Erzählung: Zeitgeschichtliche Perspektiven auf die Bundesrepublik (Göttingen, 2016), 203-18; J. Osterhammel and N.P. Petersson, Geschichte der Globalisierung: Dimensionen, Prozesse, Epochen (Munich, 2003).

${ }^{18}$ Statistisches Landesamt Hamburg, Statistisches Jahrbuch 1959 (Hamburg, 1959), 117.
} 
companies, produced up-to-date general cargo vessels as well as huge oil tankers. In 1960, western European shipyards built 81 per cent of merchant vessels. ${ }^{19}$ Half a century later, they constructed merely 3 per cent. ${ }^{20}$ Nearly all shipyards in Hamburg closed down as a result of relocation. Only Blohm + Voss survived because it limited itself to building warships and repairing old vessels. In 2010, only 2,400 employees in Hamburg still worked in shipbuilding. ${ }^{21}$ At the same time, new industrial cores arose. Shipyards from Japan, South Korea and China became increasingly important. The Asian world market share expanded from 12 per cent in 1960 to 93 per cent in 2010. ${ }^{22}$ While Hamburg's shipbuilding declined, the local shipping companies continued to play a major role, especially in the early 2000s. Massive tax breaks and financial speculation accelerated their growth. Within a few years, they ordered hundreds of new containerships, primarily from East Asia. In 2006, German shipping companies owned a third of the world container fleet. ${ }^{23}$ This business model collapsed in the course of the global financial crisis. Many investors lost their money, among them Hamburg's municipal investment bank, HSH Nordbank, which had to be bailed out.

The second dimension: from industrial production to creativity. Until the early 1970s, industrialization and urbanization were closely linked. ${ }^{24}$ Large shipyards and heavy industries dominated the port area. In addition, many small suppliers were based in the backyards of urban neighbourhoods. Every morning, hundreds of thousands of blue-collar workers swarmed into the factories, which were located all over the city. Shipyards and their subcontractors were crucial for the urban economy. They were also strongholds of the unions, and the labour movement was one of the major forces that shaped the city's development in the boom years. To strengthen economic growth and thereby create new jobs, the social democratic politicians planned to attract further large industrial sites like refineries, chemical plants and steel mills. Their goal was to overcome 'underindustrialization'. ${ }^{25}$

Yet, economic planning failed almost completely as de-industrialization set in. Since the 1970s, many factories shut down. The port area shrank and industrial wasteland spread out. Meanwhile, the service sector expanded. The increasing number of white-collar workers generated a growing demand for new office buildings. There were also considerable shifts inside the service sector. During the boom years, most services were still subordinated to industrial production. Above all, the management of international industrial enterprises expanded. When the creative

\footnotetext{
${ }^{19}$ Lloyd's Register of Shipping, Statistical Tables 1961 (London, 1961), 25.

${ }^{20}$ Institut für Seeverkehrswirtschaft und Logistik, Shipping Statistics Yearbook 2011 (Bremen, 2011), 269 et seq.

${ }^{21}$ Statistikamt Nord, Statistisches Jahrbuch Hamburg 2011/2012 (Hamburg, 2012), 136.

${ }^{22}$ Lloyd's Register of Shipping, Statistical Tables 1961, 25; Institut für Seeverkehrswirtschaft und Logistik, Shipping Statistics Yearbook 2011, 269 et seq.

${ }^{23}$ Thomas Schulz, 'Schneller, größer, Meer', Der Spiegel, 17 Feb. 2007, 80-3, quote at 81.

${ }^{24} \mathrm{M}$. Heßler and C. Zimmermann, 'Einleitung: Neue Potenziale historischer Industriestadtforschung', Informationen zur modernen Stadtgeschichte, 43 (2012), 6-14; J. Reulecke, Geschichte der Urbanisierung in Deutschland (Frankfurt am Main, 1985).

${ }^{25}$ Helmuth Kern, Ein Modell für die wirtschaftliche Entwicklung der Region Unterelbe (Hamburg, 1970), 22.
} 
industries gained prominence, the service sector changed profoundly. In the 1980s, the large publishing houses and their subcontractors - from advertising agencies to freelance journalists - became increasingly important. In the 1990s, a new working world emerged. Since then, not industrial mass fabrication, but the production of knowledge, images and lifestyles have determined key parts of the urban economy. ${ }^{26}$ During the 1990s, entrepreneurs founded numerous new media start-up companies. And in the 2000s, the debate about the creative class strongly influenced economic policy. Managers, town planners and politicians repeatedly discussed creativity. About 64,000 employees worked in the creative industries in $2007 .{ }^{27}$ In addition, 13,300 enterprises were registered, among them many freelancers. ${ }^{28}$ Because of these developments, the central office district expanded into former port and industrial areas. New office buildings replaced old harbour sheds. Beyond that, the conversion of old factories became a major theme of contemporary architecture. Many start-up companies moved into redesigned factory buildings. At the beginning of the twenty-first century, industrial production had lost its dominant role. Most factories had vanished from the inner city. The number of blue-collar workers in Hamburg had decreased from 399,000 in 1960 to 89,000 in 2010. ${ }^{29}$ The shrinking industrial sector had transformed itself. New branches like the aviation industry, which were based on scientific knowledge, gained momentum.

Two different large-scale projects illustrate this rupture. Until the 1970s, Hamburg's economic policy focused on infrastructure development, and the creation of industrial production sites. One of the major projects of the late boom years was a deep-water port in the Elbe's river mouth. ${ }^{30}$ The economics senator for Hamburg Helmuth Kern intended to raise a 1,200 hectares land area around two islands. ${ }^{31}$ Next to huge docks for supertankers and bulk carriers, he planned a gigantic industrial area for chemical plants, steel mills, shipyards and a nuclear power station. In the end, however, Hamburg's deep-water port was never realized. Instead, the city reframed its economic policy, especially after the 1980s. A growing number of politicians were convinced that future economic growth would depend on the new ideas of highly qualified workers. Soft location factors like culture became increasingly critical for this reason. In the early 2000s, mayor Ole von Beust decided to construct a new concert hall, the Elbphilharmonie, in a former port area. ${ }^{32}$ The Swiss star architects Jacques Herzog and Pierre de Meuron designed a spectacular building, which combined the redbrick walls of an earlier storehouse with an expressive glass sculpture. This cultural building was supposed

\footnotetext{
${ }^{26}$ A. McRobbie, Be Creative: Making a Living in the New Culture Industries (Cambridge, 2016); A. Reckwitz, Die Erfindung der Kreativität: Zum Prozess gesellschaftlicher Ästhetisierung (Berlin, 2012).

${ }^{27}$ Behörde für Stadtentwicklung und Umwelt, Kreative Milieus und offene Räume in Hamburg (Hamburg, 2010), 30.

${ }^{28} \mathrm{Ibid}$., 30 et seq.

${ }^{29}$ Statistisches Landesamt, Statistisches Jahrbuch 1961. Freie und Hansestadt Hamburg (Hamburg, 1961), 95; Statistikamt Nord, Statistisches Jahrbuch Hamburg 2012/2013 (Hamburg, 2013), 92.

${ }^{30} \mathrm{C}$. Strupp, 'Kooperation und Konkurrenz: Herausforderungen der Hamburger Hafenwirtschaftspolitik in den 1960er und 1970er Jahren', Zeitgeschichte in Hamburg, 9 (2011), 31-54.

${ }^{31}$ Behörde für Wirtschaft und Verkehr Hamburg, Hafen Hamburg: Konzepte für morgen. Entwicklungsplan (Hamburg, 1976), attachment.

${ }^{32}$ D. Meyhöfer, HafenCity Hamburg Waterfront: Architekturführer (Hamburg, 2014).
} 
to create a new image of the city and thereby attract the 'creative class' ${ }^{33}$ and tourism. Public-private partnership was supposed to guarantee a fast and cost-effective building process. Instead, it led to delayed completion and spiralling costs. When the Elbphilharmonie opened in 2017, the city administration had spent 789 million euros on soft location factors. ${ }^{34}$

The third dimension: from rationalization to digitalization. During the boom years, assembly lines were the key technology in industrial production. Engineers subdivided the work process into simple individual operations and rearranged them alongside conveyers. Their relentless rhythm was designed to increase productivity. Because this form of rationalization required mass production, it was limited to consumer goods industries at first. ${ }^{35}$ In the post-war period, the new scientific guidelines diffused into sectors of the economy which until then were characterized by individual construction and craftsmanship. After engineers had introduced the mass production of pre-products, they were able to restructure these sectors, among them the building industry. Assembly line workers, who produced large concrete slabs, replaced bricklayers on site. At the same time, the prefabricated building units shaped the aesthetics of modernist architecture, most notably by building multistorey tower blocks in large housing estates. And the new principles were not limited to industrial production. Even administrative work in large companies and domestic work in private households was adjusted on that basis. Assembly line production transformed the existing work organization, but hard physical labour and routine activities remained central to production.

This situation changed radically when computers supplanted assembly lines as the most important technology. Since the 1950s, computers had become increasingly powerful, as focus shifted from mainframes to personal computers to the internet. By the 1990s, digitalization dominated offices and factories. ${ }^{36}$ One of the fundamental effects was that many routine activities were automated. Because productivity increased sharply, entire groups of blue- and white-collar workers became dispensable. Digital technologies began to solve complex tasks. Computer-aided design, which the aircraft industry developed, enabled the automatic production of non-standard elements. Soon, this innovation spread to other sectors, among them the building industry. A growing number of architects used this technology to realize new constructions. Since then, representative buildings have been shaped by complex, fractured and flowing forms.

General cargo handling exemplifies how new technologies transformed daily routine. Until the 1960s, it required hard physical work. Dozens of stevedores loaded and unloaded one single merchant vessel. Many unskilled casual workers could make a living on the docks. This situation began to change when

\footnotetext{
${ }^{33}$ R.L. Florida, The Rise of the Creative Class and How It's Transforming Work, Leisure, Community and Everyday Life (New York, 2004).

${ }^{34}$ Elbphilharmonie soll 789 Millionen Euro Kosten, www.ndr.de/nachrichten/hamburg/Elbphilharmoniesoll-789-Millionen-Euro-kosten,elbphilharmonie821.html, accessed 17 Jan. 2018.

${ }^{35}$ A. von Saldern and R. Hachtmann, 'Das fordistische Jahrhundert: Eine Einleitung', Zeithistorische Forschungen, 6 (2009), 174-85.

${ }^{36}$ M. Heßler, 'Zur Persistenz der Argumente im Automatisierungsdiskurs', Aus Politik und Zeitgeschichte, 66 (2016), 17-24; P. Staab, 'The next great transformation: Ein Vorwort', Mittelweg 36, 24 (2015), 3-13.
} 
Hamburg's first container terminal started operations in $1968 .^{37}$ Containerization was closely linked to digitalization from the beginning. In addition to new cranes, the container terminal Burchardkai was equipped with a mainframe. ${ }^{38}$ In the following decades, container and computer revolutionized dock labour. In the early 2000s, port companies imposed a completely new work organization, in particular in the container terminal Altenwerder. ${ }^{39}$ Computer-controlled cranes and vehicles executed most of the work. Even though the container handling boomed, fewer stevedores found work. The growth of port handling was no longer linked to the growth of employment. While Hamburg's port handling increased from 47 million tons in 1970 to 86 million tons in 2000, the number of dockworkers declined from 14,900 to $4,800 .^{40}$ In the 1960 s, harbour areas were crowded; in the 2000 s vast parts were deserted.

The fourth dimension: from centralization to networks. Size was equivalent to performance until the early 1970s. Everything became bigger. Technologies like supertankers, nuclear power stations, assembly lines and mainframes set the trend. In addition, architects promoted a leap in dimensions. More tower blocks shaped office districts as well as large housing estates. This leap in dimensions was related to big corporations and centralized state planning from the beginning. Because large-scale technologies and buildings required major investments, they demanded economic concentration - some of the planning horizons overstrained even the capacities of big corporations - and ultimately, government subsidies, which were approved by social democratic politicians convinced that state intervention was a necessary counterpart to speculation and market forces.

In the early 1970s, this trend towards centralization reached its peak and then collapsed. ${ }^{41}$ In particular, the new social movements challenged the agglomeration of large-scale technology, economic power and state planning. Due to the antinuclear and squatters' movements, several major projects failed. Furthermore, technological innovations undermined centralization. Personal computers and the internet enabled an extensive decentralization. Not size, unity and linearity but downsizing, diversity and complexity were now equivalent to performance. With the breakthrough of the internet networks came the basic principle of organization. ${ }^{42}$ Simultaneously, the rise of financial markets replaced state planning in many sectors. These different developments drove the dot-com bubble in the late

\footnotetext{
${ }^{37}$ C. Strupp, 'Im Bann der "gefährlichen Kiste". Wirtschaft und Politik im Hamburger Hafen', in Forschungsstelle für Zeitgeschichte in Hamburg (ed.), 19 Tage Hamburg, 129-43.

${ }^{38}$ W.A. Krause, 'Elektronische Rechenanlagen. Ihr Einsatz in Häfen und Hafenbetrieben', in Hansa. Zeitschrift für Schiffahrt, Schiffbau und Hafen, 108 (1971), 376-8, quote at 376.

${ }^{39}$ O. Driesen, Welt im Fluss: Hamburgs Hafen, die HHLA und die Globalisierung (Hamburg, 2010), 172 et seq.

${ }^{40}$ Statistisches Landesamt Hamburg, Hamburger Statistisches Jahrbuch 2001/2002 (Hamburg, 2001), 174; M. Abendroth et al., Vom Stauhaken zum Container: Eine vergleichende Untersuchung der tariflichen und betrieblichen Regelungen der Hafenarbeit in den norddeutschen Häfen (Stuttgart, 1981), 80; GHB, Jahresbericht der Gesamthafenbetriebs-Gesellschaft Hamburg 2000 (Hamburg, 2001), 6.

${ }^{41}$ D. van Laak, 'Planung, Planbarkeit und Planungseuphorie, Version: 1.0', in Docupedia-Zeitgeschichte, http://docupedia.de/zg/Planung, accessed 30 Oct. 2017; M. Revelli, Die gesellschaftliche Linke: Jenseits der Zivilisation der Arbeit (Münster, 1999).

${ }^{42}$ L. Boltanski and Ė. Chiapello, The New Spirit of Capitalism (London, 2005); M. Castells, The Rise of the Network Society: The Information Age, vol. I (Cambridge, 1996).
} 
1990s. Venture capital, internet technology and countercultural movements strongly influenced many start-up companies. Despite the crash, networks became even more important during the 2000s. Today, large companies, economic policy and urban development favour small structures.

The inner city changed fundamentally in recent decades. During the boom years, a fragmented ownership structure and small buildings still characterized urban neighbourhoods. Public opinion considered them as relics of the past. In this context, state- and union-owned housing associations pushed new urban planning concepts. They wanted to expropriate the owners, demolish the old buildings and construct huge tower blocks, for example the Alsterzentrum. ${ }^{43}$ Next to the main station, the union-owned housing association Neue Heimat planned five interconnected high-rise buildings. Their 63 floors were designed to accommodate apartments for 20,000 residents, offices and shops for 15,000 employees and parking spaces for 16,000 cars. ${ }^{44}$ In the 1970 s, the housing associations failed to realize these major projects because the local landlords refused and the costs were too high. Additionally, the new social movements, which emerged after the revolt of 1968, gained influence. Their criticism encouraged a new generation of architects to abandon modernism. Instead, these architects rediscovered the value of small-scale, mixed-use and old buildings. In the early 1970s, the well-known architecture critic Manfred Sack initialized a pilot project on urban renewal. ${ }^{45}$ His main goal was to improve the living conditions in the poor urban neighbourhood Ottensen, without demolishing the buildings, expropriating the owners and replacing the residents. And in the 1980s, thousands of activists squatted in vacant houses, among them the Hafenstraße in St Pauli. ${ }^{46}$ In 1987, the conflict escalated. While 6,000 policemen prepared for eviction, the squatters built massive barricades. ${ }^{47}$ Their pirate radio issued a call to join the resistance. Finally, Hamburg's mayor Klaus von Dohnanyi decided to avoid further riots. He gave a speech on television, in which he directly addressed the squatters. He asked them to remove the barricade. He then would sign a lease agreement. In the course of the 1970s and 1980s, Hamburg's municipal government turned away from large-scale slum clearance in favour of urban regeneration. Small media companies began to move into the urban neighbourhoods. This development gained momentum in the 1990s, when entrepreneurs founded internet start-ups in the backyards of the inner city. ${ }^{48}$

The fifth dimension: from functional zoning to blurred boundaries. The clear distinction between work and life was a hallmark of urban planning in the 1950s

\footnotetext{
${ }^{43}$ N. Baues, 'Konkrete Stadtutopie: Alsterzentrum in St. Georg', in U. Höhns (ed.), Das ungebaute Hamburg: Visionen einer anderen Stadt in architektonischen Entwürfen der letzten hundertfünfzig Jahre (Hamburg, 1991), 188-99.

${ }^{44}$ Neue Heimat, Das Alsterzentrum: Ein Vorschlag zur Erneuerung des Hamburger Stadtteils St. Georg (Hamburg, 1966), 11.

${ }^{45} \mathrm{G}$. Kähler, Von der Speicherstadt bis zur Elbphilharmonie. Hundert Jahre Stadtgeschichte Hamburg (Munich, 2009), 168-70.

${ }^{46} \mathrm{M}$. Sigmund, 'Die Hafenstraße und das "Wunder von Hamburg"', in Forschungsstelle für Zeitgeschichte in Hamburg (ed.), 19 Tage Hamburg, 264-79.

${ }^{47}$ 'Hafenstraße: "Sie sind das C in der SPD"', Der Spiegel, 23 Nov. 1987, 24-31, quote at 24 et seq.

${ }^{48}$ R. Martens and G. Zint, St. Pauli: Kiez, Kult, Alltag (Hamburg, 2000).
} 
and 1960s. ${ }^{49}$ The important modernist manifesto, the Athens Charter, demanded that the basic functions of dwelling, recreation, work and transportation should be separated. ${ }^{50}$ Work organization was based on similar principles. Blue-collar and white-collar workers were supposed to be subordinate to the in-plant machinery. Random encounters and personal conversations were to be avoided. Private habits were potential sources of irritation. This tendency culminated in new office districts, which were solely composed of office buildings and therefore limited to work. Their counterparts were suburban neighbourhoods and large housing estates. Married white-collar workers, who commuted between their suburban homes and their inner-city workplaces, were powerful role models. Another separation, which characterized suburbia, was between wage-work and unpaid housework. Full-time housewives were another central social figure of the boom years.

From the late 1960s, more inhabitants were dissatisfied with these separations. This discontent became one of the essential social problems of the Fordist city. The public debated deserted office districts, uniform large housing estates and desolate suburban neighbourhoods. Countercultural adolescents tried to escape from everyday boredom. And contemporary feminists began to criticize the social isolation of housewives. Outworn urban neighbourhoods were simultaneously converted into desired destinations. Countercultural groups moved into vacant buildings and experimented with new ways of living beyond permanent jobs and nuclear families. One of their main goals was to overcome the separation between life and work. Work should be fun. At the turn of the millennium this countercultural way of living strongly influenced work organization, particularly in the creative industries. A growing number of company managers discovered that blurred boundaries were a means to increase productivity. ${ }^{51}$ Project work, soft skills and work-life balance became crucial concepts. At the same time, urban design changed profoundly. The office districts, which town planners drafted in the 1990s and 2000s, mixed office buildings, residential properties and cultural institutions.

Two different office buildings illustrate how closely urban design was linked to work organization. In the early 1960s, the municipal government demolished one of the last historic residential areas within the central business district because the food corporation Unilever wanted to construct a modern high-rise building. Politicians, architects and managers agreed to limit this part of town to offices and shops. In 1963, Unilever's white-collar workers moved into the new high rise. $^{52}$ In addition to town planning, the strict separation of life and work also shaped the internal organization of the building. Based on one single grid, the architects designed windows, floor plans, office chairs and desks. Open plan offices provided a formal working atmosphere. Clerks had to subordinate themselves to

\footnotetext{
${ }^{49} \mathrm{~J}$. Kocka, 'Mehr Last als Lust: Arbeit und Arbeitsgesellschaft in der europäischen Geschichte', Jahrbuch für Wirtschaftsgeschichte, 46 (2005), 185-206.

${ }^{50} \mathrm{E}$. Rubin, 'The Athens Charter', Themenportal Europäische Geschichte, 1 Jan. 2009, www.europa.clioonline.de/2009/Article=372, accessed 24 Jan. 2018.

${ }^{51}$ U. Bröckling, Das unternehmerische Selbst: Soziologie einer Subjektivierungsform (Frankfurt am Main, 2007); K. Gottschall and G.G. Voß (eds.), Entgrenzung von Arbeit und Leben: Zum Wandel der Beziehung von Erwerbstätigkeit und Privatsphäre im Alltag (Munich, 2003).

${ }^{52}$ O. Jungnickel, Unilever-Haus Hamburg (Munich, 1966).
} 
'the rational rules of industrial society'. ${ }^{53}$ In the 2000s, Unilever's work organization changed fundamentally. The managers now called for flexible, self-motivated and creative staff members. To meet these demands, they decided to construct an up-to-date office property for their 1,200 employees. ${ }^{54}$ The property, which opened in 2009, was located in the new office district HafenCity. ${ }^{55}$ There, the municipal government enforced a mixed-use development. Accordingly, Behnisch Architects designed Unilever's office building and a luxurious residential tower side by side. Within the office building, they blurred the boundaries between life and work. They combined office chairs and desks with bar stools and sofas. Every clerk could choose between different working areas. The informal atmosphere was expected to stimulate new ideas and increase job satisfaction. Or, as one of the architects puts it: 'In no case it should be a place, which reminds me that I am working. ${ }^{56}$

The sixth dimension: from social security to precarity. In the boom years, the labour movement was one of the main political forces in Hamburg. Due to steady economic growth and full employment, trade unionists and social democratic politicians fought successfully for social security. ${ }^{57}$ The post-war welfare state was centred on permanent jobs and the nuclear family. Starting from this basis, it gradually incorporated the margins of society. Poverty was supposed to become history. The labour movement particularly focused on dwelling. To overcome housing shortage, which war damages and the aftermath of industrialization had caused, the public sector subsidized non-profit housing associations. These union- and state-owned companies constructed dozens of large housing estates, in close collaboration with modernist architects. Tens of thousands of well-appointed council flats improved the living conditions of white- and blue-collar workers and their families in these years. At the same time, two points of rupture were on the horizon. First, the social rights of housewives mainly depended on their marriage to a wage-earning husband. For this reason, politicians did not consider the already large proportion of female part-time employment as problematic. Second, politicians viewed migrant workers as 'guest workers' expected to return to their countries of origin after working in Germany and, therefore, did not fully include them in the welfare state. While German white- and blue-collar workers moved into new apartments, many migrants still had to live in informal housing.

In the 1970s and 1980s, the expansion of the welfare state came to an end. One of the main reasons was the decline of the labour movement. Every factory which shut down weakened the unions. As mass unemployment and poverty spread, union members were afraid of losing their jobs. Social democratic politicians increasingly failed to improve the living conditions of their voters. Finally, a major corruption scandal led to the liquidation of the union-owned housing association Neue Heimat. By the end of the 1980s, the labour movement had lost most of its influence, especially on urban planning. The public sector cut the budget for

\footnotetext{
${ }^{53}$ Ibid., 10.

${ }^{54}$ M. Wassink, 'Unilever zieht in die HafenCity', Hamburger Abendblatt, 28 Mar. 2006, 26.

${ }^{55}$ U. Sengmüller, Behnisch Architekten, Stuttgart: Unilever-Haus, Hamburg (Munich, 2011).

${ }^{56}$ Work Hard - Play Hard, dir. Carmen Losmann, Germany 2011, TC: 4:53-5:00.

${ }^{57}$ R. Castel, From Manual Workers to Wage Labourers: Transformation of the Social Question (London, 2003).
} 
social housing and architecture and urban design was altered as well. The new generation of postmodern architects lost interest in social issues. Instead, they returned to representative buildings. In the 1990s and 2000s, conditions got worse. Precarity had a negative impact on significant parts of the population. ${ }^{58}$ Decades of mass unemployment had consolidated the lack of prospects and general impoverishment. Moreover, a grey area emerged between open-ended full-time contracts and unemployment. Temporary work, marginal employment and false selfemployment proliferated. Above all, precarious working and living conditions affected single mothers and migrants. Hamburg's politicians also changed their tune in the late 1990s. They now argued that due to global competition they had to strengthen the top performers. Even social democrats looked towards the global elites and lost interest in social housing. Because their new main goal was to attract creative and entrepreneurial residents, they concentrated on showcase projects like the HafenCity.

The decline of social housing exemplifies the rupture between social security and precarity. In the late 1960s, Hamburg's building industry manufactured up to 18,000 new apartments per year, most of them council flats. ${ }^{59}$ Although the expansion slowed down in the 1970s, non-profit housing companies still completed several additional large housing estates. In 1980, 45 per cent of all apartments in Hamburg were council flats. ${ }^{60}$ Since then, residential construction has been transformed. With few exceptions, housing companies no longer realized large housing estates. In the following decades, the building industry manufactured far fewer new apartments. In 2007, it only completed about 3,000, many of them condominiums. ${ }^{61}$ Simultaneously, housing enterprises converted council flats into regular flats. Social housing was radically reduced. In 2010, only 11 per cent of all apartments in Hamburg were still council flats. ${ }^{62}$

The seventh dimension: from suburbanization to the renaissance of the inner city. Suburbanization was one of the crucial social trends of the boom years. ${ }^{63}$ Driven by mass motorization, conservative housing policy and low land prices, suburban neighbourhoods expanded. Young middle-class families fulfilled their desires and moved into separate houses with small gardens. The suburban neighbourhoods of the post-war period were rooted in the exclusive residential districts of the late nineteenth century. And still the inhabitants, who strove for social advancement,

\footnotetext{
${ }^{58}$ O. Marchart (ed.), Facetten der Prekarisierungsgesellschaft: Prekäre Verhältnisse. Sozialwissenschaftliche Perspektiven auf die Prekarisierung von Arbeit und Leben (Bielefeld, 2013); R. Castel and K. Dörre (eds.), Prekarität, Abstieg, Ausgrenzung: Die soziale Frage am Beginn des 21. Jahrhunderts (Frankfurt am Main, 2009).

${ }^{59}$ J. Brohm, 'Wohnungsbau. Wandlungen im Wohnungsbau in der Zeit von 1969-1984', in Architektenund Ingenieur-Verein Hamburg (ed.), Hamburg und seine Bauten 1969-1984 (Hamburg, 1984), 406-10, quote at 406 .

${ }^{60}$ Senat Hamburg, Stadtentwicklungskonzept (Hamburg, 1980), 56.

${ }^{61}$ Statistikamt Nord, Statistisches Jahrbuch Hamburg 2012/2013, 81.

${ }^{62}$ Statistisches Amt für Hamburg und Schleswig-Holstein, Hamburger Stadtteil-Profile 2010 (Hamburg, 2010), 23.

${ }^{63}$ C. Zimmermann, 'Die "Suburbanisierung" als Konzept der Stadt-Land-Beziehungen', in F.-W. Kersting and C. Zimmermann (eds.), Stadt-Land-Beziehungen im 20. Jahrhundert: Geschichts- und kulturwissenschaftliche Perspektiven (Paderborn, 2015), 55-68; T. Harlander (ed.), Villa und Eigenheim: Suburbaner Städtebau in Deutschland (Stuttgart, 2001).
} 
turned away from the industrialized city. Unlike suburban sprawl, large housing estates were shaped through extensive planning processes, but most of them were also built at the margins of the city. Suburbanization also affected work. Department stores and self-service shops followed their customers. Expanding business administrations resettled in new office districts, which were constructed in the outskirts. It was intended that additional industrial production sites be situated in the metropolitan area. While the focus of urban development shifted outwards, the decline of the inner city accelerated. Because of their high density, their chaotic mix of residential buildings and backyard factories and their small scale, opinion leaders rejected the centrally located living districts as relics of the past. Those residents who could afford it moved into the suburbs. To counteract depopulation, local politicians and town planners promoted slum clearance, particularly in St Georg, St Pauli and Ottensen, where World War II had destroyed only parts of the built environment. These large-scale projects, which they planned in the late 1960s, were never realized. Instead, migrant workers and their families as well as young members of the counterculture moved into the vacant buildings.

In the 1980s, the focus of urban development shifted again. The process of suburbanization lost its dynamic. Suburban neighbourhoods grew slower, large housing estates were no longer planned and the industrial settlements had failed: the renaissance of the inner city began. ${ }^{64}$ Many singles, gay couples and patchwork families no longer wanted to live in suburbia. Instead, they decided to stay in the city. Town planners started to redirect urban growth by, for instance, converting industrial wasteland into new quarters while local politicians adjusted their economic strategy to the new concept of the business cluster. They began to consider the agglomeration of companies, subcontractors and research institutes as preconditions of economic growth. The perception of centrally located living districts altered profoundly. Relics of the past became models of the future, not despite their high density, their chaotic mix of residential buildings and backyard factories and their small scale but because of these factors. These urban neighbourhoods began to attract a new middle class and finally venture capitalists. As rents rose, unemployed and poor residents as well as students and artists were forced out. Protests against gentrification erupted.

Changing town planning concepts illustrate this shift from suburbanization to the renaissance of the inner city. In 1970, Helmuth Kern published an ambitious model. ${ }^{65}$ In future decades, the city was supposed to grow alongside different 'development axes' ${ }^{66}$ which expanded from the city centre into the region. These development axes, in which huge park areas separated from each other, were to be composed of large housing estates and above all industrial production sites. A dozen nuclear power plants were supposed to attract steel mills and chemical plants. ${ }^{67}$ When the economic crisis set in, this ambitious economic model collapsed. By the end of the 1970s, politicians and town planners were sceptical

\footnotetext{
${ }^{64}$ K. Brake and G. Herfert (eds.), Reurbanisierung: Materialität und Diskurs in Deutschland (Wiesbaden, 2012); Häußermann et al., Stadtpolitik.

${ }^{65}$ Kern, Modell für die wirtschaftliche Entwicklung.

${ }^{66} \mathrm{Ibid}$., attachment.

${ }^{67}$ Hier entsteht ein neuer Ruhrpott, in Der Spiegel, 28 Oct. 1974, 49-67, quote at 52.
} 
about large-scale planning. Because they had to solve the urgent problems of a shrinking city, they pursued a pragmatic approach. In the late 1990s, politicians and town planners abandoned their restraint. They once again made a commitment to accelerate the growth of the economy and population, but they no longer concentrated on the region. Instead, they wanted to redirect growth to the city centre. In 2002, Hamburg's mayor Ole von Beust published an overall plan for economic development, which promoted several business clusters, among them IT and media, logistics, trade with China and the aviation industry. ${ }^{68}$ And in 2007, the head of town planning Jörn Walter released new guiding principles, which focused on converting former harbour areas into new urban districts. ${ }^{69}$

\section{From Hamburg to European cities}

The relationship between working worlds and urban spaces in Hamburg has been revolutionized since the 1970s. Simultaneously, questions about the coverage of the case-study arise: does it allow conclusions to be drawn about the rest of the continent? Is it limited to north-west European cities? Does it refer only to port cities? Or does it solely refer to the individual characteristics of Hamburg? I cannot answer these questions completely, but certain built environments, which characterized the radical change, give guidance. In Hamburg, one of them was the conversion of waterfront and industrial areas. If one can observe those conversions in other European cities, then this suggests that similar transformations took place.

Until the 1960s, large port areas and industrial sites dominated the urban centres of north-west European port cities, but in the course of the 1970s and 1980s, economic change accelerated. ${ }^{70}$ Two breakpoints were crucial: containerization replaced the former general cargo handling - while port companies constructed new container terminals out of town, the docks within the city lost their relevance and most of the shipbuilding industry was relocated to East Asia. Because world competition was too strong, one European shipyard after another shut down. For these reasons, wastelands spread out in urban centres. Unemployment and impoverishment were on the rise. At the same time, reusing wasteland became one of the key topics of urban development, especially in the 1990s and 2000s. Residential buildings, parks, cultural institutions, shopping centres and office buildings replaced docks and shipyards. New jobs were created, in particular for high-skilled workers.

British port cities were trendsetters, from the London Docklands to the Clyde Auditorium in Glasgow. ${ }^{71}$ In the years to come, many north-west European port cities realized similar projects, for example Dublin, Oslo, Gothenburg, Copenhagen, Amsterdam, Rotterdam and Antwerp. ${ }^{72}$ Since the 1990 s, one can

\footnotetext{
${ }^{68}$ Staatliche Pressestelle Hamburg, Leitbild: Metropole Hamburg - Wachsenden Stadt (Hamburg, 2002).

${ }^{69}$ Behörde für Stadtentwicklung und Umwelt Hamburg, Räumliches Leitbild. Entwurf (Hamburg, 2007).

${ }^{70} \mathrm{C}$. Bernhardt, 'Stadt am Wasser', Informationen zur modernen Stadtgeschichte, 34 (2003), 4-13.

${ }^{71}$ T. Gerstung, Stapellauf für ein neues Zeitalter: Die Industriemetropole Glasgow im revolutionären Wandel nach dem Boom (1960-2000) (Göttingen, 2016); S. Williams, Docklands (London, 1993); B. Edwards, London Docklands: Urban Design in an Age of Deregulation (Oxford, 1992).

${ }^{72} \mathrm{~B}$. Doucet, Rich Cities with Poor People: Waterfront Regeneration in the Netherlands and Scotland (Utrecht, 2010); D. Schubert (ed.), Hafen und Uferzonen im Wandel: Analysen und Planungen zur
} 
observe related transitions in southern European port cities, above all in Barcelona. Local politicians used the Summer Olympics of 1992 as a tool for realizing urban renewal. ${ }^{73}$ Because Barcelona had been a centre of cotton trade, many textile factories had settled in the district El Poblenou. Until the 1970s, industrial production determined this part of town. Then de-industrialization began. Town planners therefore decided to build the Olympic Village in El Poblenou. Residential buildings for athletes and large parks replaced vacant factories. When the sports event had ended, upper-middle-class families moved into the apartments. The Summer Olympics were a key element in adjusting the city's economy. While docks and industrial sites disappeared, service, culture and tourism shaped the urban centre. Poor inhabitants were displaced. One can find similar urban developments in other southern European port cities, for example Expo 1992 in Genoa, Euroméditerranée in Marseille, Abandoibarra in Bilbao and Expo '98 in Lisbon. ${ }^{74}$ Such projects had not previously existed in eastern European cities, but in the 2000s the first plans emerged. In Gdańsk, office buildings, cultural institutions and residential properties were to replace the famous Lenin shipyard. ${ }^{75}$

Conversions of urban docks and shipyards indicate that European harbour cities changed radically in the last decades of the twentieth century. This transition was not limited to ports. In many other European cities, industrial production has lost its central role, most notably in urban areas, where coal mining and steel production played a crucial role. One of the most important areas was the Ruhr. The region's mines and blast furnaces, which dominated life and work until the 1960s, shut down almost completely in the following decades. By the late 1980s, industrial wastelands had spread out. These brownfields were converted when the Internationale Architecture Exhibition Emscher Park took place from 1989 to 1999. One major part of the exhibition was the Industrial Heritage Trail, which assembled 25 former production sites, among them the Zollverein Coal Mine Industrial Complex in Essen. ${ }^{76}$ Architects reused this industrial complex, which closed in 1986, for museums, restaurants and cafes. In the Ruhr area, the International Architecture Exhibition Emscher Park was only one of several large-scale projects. Since 2001, Dortmund's municipal government and investors have pushed the regeneration of the closed down Phoenix steel mill. In the 200-hectares site, they have realized a high-tech centre, an office district, cultural

Revitalisierung der Waterfront in Hafenstädten (Berlin, 2001); A. Priebs, 'Hafen und Stadt: Nutzungswandel und Revitalisierung alter Häfen. Herausforderungen für Stadtentwicklung und Stadtgeographie', Geographische Zeitschrift, 86 (1998), 16-30.

${ }^{73}$ H. Meyer, City and Port (Rotterdam, 1999); S. Garcia, 'Barcelona und die Olympischen Spiele', in H. Häußermann and W. Siebel (eds.), Festivalisierung der Stadtpolitik: Stadtentwicklung durch große Projekte (Opladen, 1993), 251-77.

${ }^{74}$ H.V. Savitch et al., 'Marseille. France's great port city comes back from the brink', in F. Wagner et al. (eds.), Transforming Distressed Global Communities (Farnham, 2015), 31-50; R. Marshall (ed.), Waterfronts in Postindustrial Cities (London, 2001); P. Weber and M. Schott, 'Lissabon. Stadtentwicklung zur Wasserfront', Europa regional, 9 (2001), 16-25.

${ }^{75}$ A. Tölle, Quartiersentwicklung an innerstädtischen Uferzonen: Die Beispiele Hamburg HafenCity, Lyon Confluence und Gdańsk Mlode Miasto (Berlin, 2005), 195-216.

${ }^{76} \mathrm{~A}$. Schwarz (ed.), Industriekultur, Image, Identität: Die Zeche Zollverein und der Wandel in den Köpfen (Essen, 2008); A. Höber and K. Ganser (eds.), Industriekultur: Mythos und Moderne im Ruhrgebiet. Im Rahmen der IBA Emscher Park (Essen, 1999). 
institutions, residential buildings and a large lake. ${ }^{77}$ Even in the Ruhr area, which was dominated by heavy industry for more than a century, knowledge and culture have become the main source of economic development. The widespread reuse of waterfront and industrial sites is a clear sign that a cumulative structural break has transformed European cities since the 1970s. Hamburg is no exception.

\footnotetext{
${ }^{77}$ A. Keil and B. Wetterau, Metropole Ruhr: Landeskundliche Betrachtungen des neuen Ruhrgebiets (Essen, 2013), 30.
}

Cite this article: Neumann A (2020). From Fordist to neo-liberal urban spaces in times of de-industrialization: a conceptual frame for a complex relationship. Urban History 47, 220-235. https://doi.org/10.1017/ S0963926819000233 